\title{
Mesenteric revascularisation for acute-on-chronic intestinal ischaemia
}

\author{
Richard J Holdsworth, Zahid Raza, Sadahna Naidu, Peter T McCollum
}

\begin{abstract}
Summary
Eleven patients (eight women) underwent urgent revascularisation for acute-onchronic mesenteric ischaemia. Four patients had dual vessel and seven single vessel reconstructions. Two patients underwent simultaneous bowel resection and one patient has had three separate grafts to the superior mesenteric artery. There were two peri-operative deaths and three have died in the late follow-up period after 18, 24 and 36 months. The remainder have survived for between five and 63 months. Revascularisation for acute-on-chronic mesenteric ischaemia has been shown to be technically possible and of substantial benefit to patients who would otherwise be treated as terminal cases.
\end{abstract}

Keywords: mesenteric revascularisation, surgery, ischaemic colitis, vascular patency

Chronic intestinal ischaemia is a relatively uncommon, but probably under-diagnosed condition. The term 'abdominal angina' for the syndrome of post-prandial abdominal pain is usually attributed to Bacelli. ${ }^{1}$ Patients have pain severe enough to avoid food, marked weight loss and sometimes diarrhoea, nausea or vomiting. Other important factors in the patient's history include smoking and peripheral vascular disease. ${ }^{1,2}$ It has also been suggested that women are affected more frequently than men. The natural progression of this condition is a gradual reduction in blood supply to the abdominal viscera. Frequently, this is complicated by an acute thrombotic episode leading to bowel infarction which has a persistently high mortality rate..$^{3-5}$ We present a series of patients who underwent revascularisation procedures for acute-onchronic mesenteric ischaemia.

\section{Patients}

Eleven patients (eight women and three men) underwent urgent mesenteric revascularisation for acute-on-chronic ischaemia between 1990 and 1995 . The average age was 64 years (range 46-76). Ten patients were heavy smokers (more than 20 cigarettes per day) up to the time of operation and one patient had previously been a heavy smoker. Ten patients had peripheral vascular disease with symptoms of intermittent claudication present for between two and 18 years. All patients had a history of intermittent abdominal pain which had lasted from two weeks to nine years and all patients had a recent acute deterioration in symptoms. In three patients, the abdominal pain had become constant, one had diarrhoea, one had vomiting and seven patients had both diarrhoea and vomiting.

\section{Surgical management}

A summary of our 11 patients and their outcome is shown in the table. The median follow-up period was 30 months (range 5-60 months). All the revascularisation procedures were carried out as urgent or emergency procedures. Seven patients had a single vessel revascularisation, five superior mesenteric artery (SMA), one coeliac and one inferior mesenteric artery (IMA). The remaining four patients had dual-vessel reconstructions, three SMA/coeliac and one an SMA/IMA revascularisation.

Two patients died within 30 days of surgery, one from a gastrointestinal anastamotic dehiscence (day 12) and one from a cerebrovascular accident (day seven). Three other deaths occurred at 18, 24 and 36 months, due to a myocardial infarction, an aorto-enteric fistula and hypovolaemic shock from a ruptured femoro-popliteal bypass graft, respectively. One patient has had three separate procedures carried out on the SMA. This patient initially had an emergency aorto-SMA vein graft which blocked at 22 months. This was revised with a similar vein graft which blocked after a further 13 months. At a third emergency operation, a $6 \mathrm{~mm}$ PTFE graft was inserted and the proximal jejunum was resected for full-thickness bowel gangrene. One other patient had an occluded graft at 13 days (PTFE) and underwent a major bowel resection, necessitating total parenteral nutrition indefinitely. All the other patients became asymptomatic.

\section{Discussion}

The diagnosis of chronic mesenteric ischaemia is frequently overlooked. Patients are often subjected to a large series of investigations which may be both uncomfortable and complex, until either a diagnosis of mesenteric ischaemia is considered by exclusion ${ }^{6}$ or acute deterioration occurs. All clinicians should therefore maintain a high index of suspicion of this disease in patients with atherosclerosis because acceptable surgical morbidity can only be achieved if it is treated early. 
Table 1 Summary of the outcome of 11 patients undergoing revascularisation for acute-on-chronic mesenteric ischaemia

\begin{tabular}{|c|c|c|c|c|c|c|}
\hline $\begin{array}{l}\text { Age } \\
\text { (years) }\end{array}$ & Sex & c Operation & Graft type & Inflow of graft & Graft complication & Outcome \\
\hline 76 & $\mathbf{F}$ & aorto-SMA bypass & Vein & supra-renal aorta & $\begin{array}{l}\text { Second-look laparotomy at } 24 \mathrm{~h} \\
\text { Cholecystectomy for } \\
\text { acalculous gangrenous } \\
\text { cholecystitis }\end{array}$ & $\begin{array}{l}\text { Died at } 12 \text { days due to } \\
\text { intra-abdominal sepsis. } \\
\text { Anastamotoic dehiscence } \\
\text { of duodeno-jejunal flexure }\end{array}$ \\
\hline 46 & $\mathbf{M}$ & aorto-SMA bypass & $6 \mathrm{~mm}$ PTFE & infra-renal aorta & $\begin{array}{l}\text { Graft occlusion at } 13 \text { days } \\
\text { Extensive small bowel } \\
\text { resection }\end{array}$ & $\begin{array}{l}\text { Died at } 24 \text { months due } \\
\text { to aorto-enteric fistula } \\
\text { and sepsis }\end{array}$ \\
\hline 75 & F & aorto-coeliac bypass & $6 \mathrm{~mm}$ PTFE & infra-renal aorta & None & $\begin{array}{l}\text { Died at } 18 \text { months due } \\
\text { to cardiac arrest }\end{array}$ \\
\hline 68 & F & $\begin{array}{l}\text { aorto-SMA bypass } \\
\text { aorto-coeliac bypass }\end{array}$ & $\begin{array}{l}\text { Vein } \\
\text { Vein }\end{array}$ & $\begin{array}{l}\text { infra-renal aorta } \\
\text { infra-renal aorta }\end{array}$ & None & Alive at 14 months \\
\hline 65 & F & aorto-bifemoral bypass & $\begin{array}{l}14 \times 7 \text { Dacron } \\
7 \mathrm{~mm} \text { Dacron }\end{array}$ & infra-renal aorta & None & $\begin{array}{l}\text { Died at } 36 \text { months due } \\
\text { to multi-organ failure }\end{array}$ \\
\hline 51 & $\mathbf{F}$ & $\begin{array}{l}\text { aorto-bifemoral bypass } \\
\text { aorto-SMA bypass } \\
\text { IMA reimplantation }\end{array}$ & $\begin{array}{l}14 \times 7 \text { Dacron } \\
6 \text { mm PTFE }\end{array}$ & infra-renal aorta & $\begin{array}{l}\text { Second-look laparotomy at } 24 \mathrm{~h} \\
\text { Two areas of bowel necrosis } \\
\text { surgically invaginated }\end{array}$ & Alive at 20 months \\
\hline 61 & $\mathbf{M}$ & $\begin{array}{l}\text { aorto-bifemoral bypass } \\
\text { SMA endarterectomy }\end{array}$ & & & None & Alive at 40 months \\
\hline 73 & F & $\begin{array}{l}\text { aorto-coeliac bypass } \\
\text { aorto-SMA bypass }\end{array}$ & $\begin{array}{l}14 \times 7 \text { Dacron } \\
\text { (bifurcated) }\end{array}$ & supra-renal aorta & None & Alive at 63 months \\
\hline 71 & F & IMA endarterectomy & & & None & $\begin{array}{l}\text { Died at } 7 \text { days due to } \\
\text { cerebrovascular accident }\end{array}$ \\
\hline 54 & $\mathbf{M}$ & $\begin{array}{l}\text { (1) aorto-SMA bypass } \\
\text { (2) aorto-SMA bypass } \\
\text { (3) aorto-SMA bypass, } \\
\text { resection of jejunum }\end{array}$ & $\begin{array}{l}\text { Vein } \\
\text { Vein } \\
6 \mathrm{~mm} \text { PTFE }\end{array}$ & $\begin{array}{l}\text { infra-renal aorta } \\
\text { infra-renal aorta } \\
\text { infra-renal aorta }\end{array}$ & $\begin{array}{l}\text { Graft occlusion at } 22 \text { months, revised } \\
\text { Graft occlusion at } 13 \text { months, revised } \\
\text { None }\end{array}$ & $\begin{array}{l}\text { Alive at } 12 \text { months from } \\
\text { last operation ( } 47 \text { months } \\
\text { from presentation) }\end{array}$ \\
\hline 68 & $\mathbf{F}$ & $\begin{array}{l}\text { aorto-coeliac bypass } \\
\text { aorto-SMA bypass }\end{array}$ & $\begin{array}{l}12 \times 6 \text { Dacron } \\
\text { (bifurcated) }\end{array}$ & infra-renal aorta & None & Alive at 5 months \\
\hline
\end{tabular}

\begin{tabular}{|l|}
\hline $\begin{array}{l}\text { Mesenteric ischaemia: clinical } \\
\text { features }\end{array}$ \\
\hline - post-prandial abdominal pain \\
- marked weight loss \\
- history suggestive of gastrointestinal \\
malignancy \\
- normal gastrointestinal investigation \\
claudication, history of stroke, or positive faecal \\
occult blood \\
\hline
\end{tabular}

Box 1

When a patient presents with mesenteric ischaemia, it is often as a result of an acute deterioration due either to mesenteric embolisation or an acute-on-chronic thrombotic occlusion. If the whole of the bowel is gangrenous there is little that can be done. However, in the event of the bowel having areas of patchy necrosis, a surgeon is faced with the difficult decision of how much bowel to resect and whether to undertake an anastamosis or bring out the ends individually. If it has been an embolic event and the embolus is lodged distally, a limited bowel resection may be possible. In a situation where there is longstanding mesenteric ischaemia and an acuteon-chronic deterioration occurs, bowel resection is a hazardous procedure if it is not accompanied by mesenteric revascularisation.

It is of interest to note that, in two of our patients, full-thickness bowel necrosis occurred at the duodeno-jejunal flexure which necessitated bowel resection. It appears that this is a watershed area between the coeliac and SMA vessels. Detailed descriptions of the blood supply to this area are unfortunately hard to
Mesenteric ischaemia: therapeutic options

- if acute deterioration occurs, it may be too late to salvage the bowel

- segmental bowel resection is very hazardous

- revascularisation offers the only satisfactory treatment

- patchy necrosis at laparotomy is an indication for revascularisation

- in an emergency, aorto-SMA bypass is the best option

- undertake second-look laparotomy after 24 hours

Box 2

find. Nevertheless, it is an area where any anastamosis is notoriously difficult and exteriorization of the bowel is not a possible alternative strategy to primary anastamosis. In this situation, mesenteric revascularisation may be particularly beneficial.

Mesenteric ischaemia is relatively rare compared to other manifestations of atherosclerosis. The rich collateral network between the three mesenteric vessels is usually sufficient to allow for normal bowel function despite occlusive disease. Severe disease of at least two of the bowel vessels is usually necessary for a patient to be symptomatic. ${ }^{6,7}$ Although some authors advocate multivessel revascularisations, ${ }^{1,8,9}$ revascularisation of one vessel is usually sufficient for the patient's symptoms to cease. ${ }^{10}$

The occlusive disease in visceral vessels is usually limited to the origin and revascularisation can easily be performed in the proximal portion of the vessel. The principal surgical risk 


\section{Summary/learning points}

- try to identify patients with chronic mesenteric ischaemia before acute deterioration occurs

- suspect in any patient with excess weight loss, normal gastrointestinal investigation and unexplained post-prandial pain

- mesenteric angiography is the next logical investigation

- despite a relatively high operative mortality, mesenteric revascularisation offers the only hope of survival and can return the gastrointestinal tract to normal

Box 3

1 Hollier LH, Bernatz PE, Pairolero PC, Payne WS Osmundson PJ. Surgical management of chronic intestina Osmundson PJ. Surgical management of chronic intes

2 McFarlane SD, Beebe HG. Progress in chronic mesenteric arterial ischaemia. $\mathcal{f}$ Cardiovasc Surg $1989 ; 30: 178-84$.

3 Heys SD, Brittenden J, Crofts TJ. Acute mesenteric ischaemia: the continuing difficulty in early diagnosis. Postgrad Med F 1993; 69: 48-51.

4 Calvian PA, Muller C, Harder F. Treatment of mesenteric ischaemia. Br $¥$ Surg 1987; 74: $500-3$

5 Ottinger LW, Austen WG. A study of 136 patients with mesenteric infarction. Surg Gynecol Obstet 1967; 124: 251 61 .

6 Fisher DF, Fry WJ. Collateral mesenteric circulation. Surg

Gynecol Obstet 1978; 164: 487-92. comes from aortic cross-clamping which can put a tremendous stress on the patient. Nevertheless, the risks of reconstructive surgery have to be weighed against their chances of survival without revascularisation. In view of the high mortality of mesenteric ischaemia, we feel that revascularisation should be attempted in all patients, and particularly when ischaemia affects the proximal jejunum.

This small series confirms that an aggressive surgical approach to acute-on-chronic mesenteric ischaemia can be justified because reconstructive surgery offers the only hope of survival in these critically ill patients.

7 Bradbury AW, Brittenden J, McBride K, Ruckley CV. Mesenteric ischaemia: a multidisciplinary approach $\mathrm{Br} \mathfrak{f}$ Mesenteric ischaemia: a

8 Baur GM, Millay DJ, Taylor LM, Porter JM. Treatment of chronic visceral ischaemia. Am f Surg 1984; 148: 138-44. 9 McAfee MK, Cherry KJ, Naessens JM, et al. Influence of complete revascularisation on chronic mesenteric ischaemia. Am f Surg 1992; 164: 220-4

10 Gentile AT, Moneta GL, Taylor LM, Park TC, McConnell DB, Porter JM. Isolated bypass to the superior mesenteric artery for intestinal ischaemia. Arch Surg 1994; 129: $926-$

Reginald Hall (1931 -94) was born and educated at Durham, where he qualified in 1956. He became an endocrinologist with a particular interest in the thyroid. He became a professor of medicine in Newcastle and then at the University of Wales, Cardiff (1979-89). He suffered cardiac amyloidosis for which he was given a cardiac transplant which kept him well for over 10 years. He died in Cardiff on 20 July 1994. - DG fames 